\title{
SOME GENERIC PROBLEMS OF SENECAN DRAMA
}

\begin{abstract}
Summary: The messenger speeches in some of Seneca's tragedies (the most extensive ones can be read in Agamemnon and Hercules Furens) constitute special epic details of the works. Their narrative technique, intertextual references and representation of time link them not with the dramatic literary form, but with the epic one, and Vergil's Aeneid is, beyond any doubt, their most important 'hypertextus'. The setting of the messenger reports has not been subordinated to the dramatic efficacy of the main conflict, they produce rather a generic multiplicity. The reform of closed literary forms and the generic heterogeneity are not unique phenomena in the literary life of this period; the meaning and importance of the innovation made by Seneca cannot be judged separately from the most important literary achievements of the period: Lucan's Bellum Civile and Petronius'Satyricon.
\end{abstract}

Key words: messenger speeches, Seneca, Agamemnon, Hercules Furens, Vergil, Aeneid, hypertextus, Lucan, Petronius.

At the beginning of the sixth chapter of his Poetics, Aristotle defines tragedy as

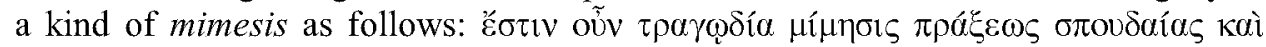

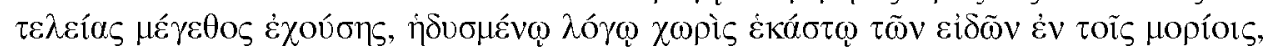

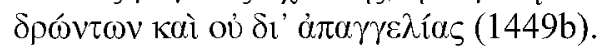

This definition that essentially follows Plato's concept, ${ }^{1}$ leaves out of consideration the problem that arises from the representation of the choir in classical drama. In the nineteenth chapter of the work, Aristotle discusses the role of the choir, remarking that we should regard it as a persona dramatis and that he regards Sophocles as a model (quite naturally, as opposed to Euripides), in whose tragedies the choirs unite with the plot in an organic way; thus they are not merely insertions.

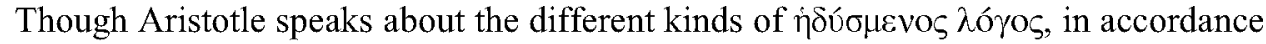
with his whole theory, he emphasizes the unity and the requirement of unity. But for us it is beyond any doubt that the choir does not really act, the text recited by them does not display praxis. For the modern reader and interpreter, the Attic tragedy is a complex of lyric poetry performed in lyric meters by the choruses, and drama displayed in the epeisodions, whose constituents can be always distinguished by our aesthetic awareness. This paper aims to analyze the way by which this unity of praxis

\footnotetext{
${ }^{1}$ Cf. Platon, Res publica, 394 b-c.
} 
displayed and lyric chorus had been extended in Senecan drama by the introduction of narrative mimesis, i.e. by the very kind of mimesis Aristotle considered as alien to the essence of drama.

The observation that Senecan tragedies contain a surprising amount of descriptive elements is, of course, nothing new, since Nisard characterized them so in the last century: "après la déclamation, la description, après la description, la déclamation." ${ }^{2}$ The aesthetic depreciation of these words will not escape the reader. The criticism of the last century (or to be more exact, of the period beginning in the last third of the 18 th century ${ }^{3}$ ) regarded the abundance of descriptive narrations as an evident deficiency, and believed to have found an explanation for this phenomenon in the rhetorical exercises characteristic for the age; it thus drew an easy parallel between the Suasoriae et controversisae of Seneca Maior and the tragedies of his son. Thus the mass of descriptive details had been adopted from the practice of rhetoric, and the aesthetic norms of the Attic trias (or rather, the norms of Aristotelian poetics) had been demanded from Senecan tragedy as well, the author had been condemned for unskilful imitation which enticed him from the routine of rhetoric. This judgement reflects the conviction that marks this period concerning the creative nature of Greek literature and the purely imitative one of Roman literature.

The abundance of descriptions also played a major role in the development of the theory of 'recitative drama'. It seemed unthinkable, on the one hand, that such plays had appeared in the practice of the stage, with the obvious conclusion on the other, that they had been designed for the public recitations mentioned several times in ancient sources. ${ }^{4} \mathrm{O}$. Zwierlein, author of the programmatic book of this theory, used the descriptive character as an important argument, that the lengthy descriptive sections are necessary to replace the missing stage setting. ${ }^{5}$ In this paper I will propose another interpretation for the nature of the descriptive sections. I would like to illustrate the theory with the analysis of messenger speeches that represent the most descriptive details of Senecan drama. My aim is to illustrate the peculiar generic character of these works through the example of the most problematic insert, at least regarding the possibility of a stage performance.

Of the seven plays written by Seneca that are now accepted as authentic, only Medea and the incomplete Phoenissae do not contain messenger speeches, while the others have a kind of speech of this type: in Thyestes and Phaedra it occurs in the penultimate epeisodion, and in the other ones in the third one. The most extended messenger speeches can be read in Hercules Furens, Agamemnon and Oedipus rex. In terms of structure, the speeches in Agamemnon and Hercules Furens show a closer relation. The report of the messenger follows a lengthy preparatory exposition of the main dramatic conflict in both plays, and thus the preliminary conclusion that they

${ }^{2}$ NISARD, M. D.: Etude de moeurs et de critique sur les poetes Iatins de la décadence. Bruxelles 1834, vol. I, 166.

${ }^{3}$ Cf. LESSING's fundamental essay, Von den lateinischen Trauerspielen, welche unter dem Namen des Seneca bekannt sind. G. E. Lessings Sämtliche Schriften. Edited by K. Lachmann. Muncker. Stuttgart 1890, vol. VI, 167-242.

${ }_{5}^{4}$ E.g. Juvenal, 1. 1; Plinius, Min. 7.17.3; Tacitus, Dialogus, 2.1.; 3. 3.

${ }^{5}$ ZWIERLEIN, O.: Die Rezitationsdramen Senecas. Meisenheim am Glan 1966, 117-119. 
have a special delaying function might seem obvious. This impression is confirmed by a more careful reading of the text inasmuch as they delay the appearance of the conflict; at the same time, the term 'delaying' is misleading, since the delaying effect has been usually subordinated to the conflict i.e. to the dramatic efficacy of the conflict. However, these tragedies show a strange and unique feature in the history of ancient dramaturgy in that the messenger episodes have a surprising independence; they undermine the efficacy and break the empathy of the recipient, rather than strengthen it. Aristotle considered a looseness of the structure of this kind and the breaking of the verisimilitude a definite fault in the representation. ${ }^{6}$

In Agamemnon, a drama of 1012 verses altogether, the first ca. 440 verses can be seen as an exposition of the conflict; after learning that her husband was returning home, Clytaemestra tries to find a rational escape from her painful situation, discussing it first with her nutrix, and then with Aegistus. Nevertheless, she is completely aware of the fruitlessness of all efforts: clausa iam melior via est (109). Before the unfaithful wife and her husband who richly deserved her infidelity meet, the messenger's speech takes place in 160 verses about the storm surprising the Mycenaean fleet on its way home. This report extends far beyond the actual dramatic situation; it is not designed to merely inform Clytaemestra or to offer her a vivid description of the naval disaster. The episode of different genre-character inserted between the exposition and the fulfilment of the conflict suspends the dramatic situation and enters into a lengthy story that is not connected with the events on stage in a direct way. In dramatic works the 'natural' time of an action and the time needed for performing it on stage is generally identical, and it gives us the impression that the characters speak or handle only as much as we can perceive from the stage. In classic Athenian tragedy, at least, the time of certain epeisodia and that of the actions performed in it are the same, and some leaping in the time happens by inserting the choruses. However, the representation of time in the narrative inserts is quite different: its rhythm and speed are determined by the narrator i.e. by the epic voice. Even though there are some events that must have happened within breathing space, they can nevertheless be described at some length, while longer actions can be summarized in very few words. In a narration of epic character not even the speeches quoted verbatim by the narrator give the impression that the report takes up the same amount of time as the narrated event since the narrator does not promise to imitate the speed and performance of the speech. Consequently, the narrative inserts interrupt the continuity of the dramatic time and with the display of a diction of another generic character, they represent a different treatment of time.

Seneca apparently strives to create the logical integrity of narrative insertions within the dramatic situation. In Agamemnon, the report of the messenger illustrates the falseness of Agamemnon's triumphator attitude and the absoluteness of divine vengeance; the report in Hercules Furens offers some important details of Hercules' journey to the underworld which enables us to judge the real character of the last athlos, to judge whether it was a heroic deed or a sacrilege. Nevertheless, these narrative inserts retain their relative independence, resembling the choruses of Attic tra-

${ }^{6}$ Cf. Poetics, 145a25-32. 
gedies. It is highly improbable, by way of illustration, that Clytaemestra who can hardly restrain her inner turmoil listens patiently to a narrative of more than 150 verses about events that hardly concern her, such as the reason and circumstances of Ajax's death. (This question is obviously connected with the problem of the possibility of a stage performance: what do the other actors present on stage, what does, in our case, Clytaemestra do during the messenger's report? Do they try to act as an attentive audience and pretend to react to what they hear or does the stage setting reinforce the insertion character of the messenger speeches, with the messenger standing practically alone on the stage?)

The scholar inevitably compares this Roman tragedy with its unique possible source that has survived in its complete form, namely with Aeschylus' Agamemnon, the first piece of the Oresteia trilogy. There is a keryx scene in the Greek tragedy too. In Aeschylus' drama, the messenger first expresses his joy upon returning home and the successful conclusion of the long war, and then proceeds to sum up the history of the storm, but without any truly descriptive details. The speaker is fully aware of the situation he is speaking in. It is out of the question that the report would be outside the frame of the dramatic situation or would suspend its validity. He describes the ordeal of the storm and the shipwreck in a few words, in no more than 30 verses altogether (650-680): the storm is related in 10 verses, the escape of Agamemnon's ship in 10 , while the last 10 verses has the messenger guessing the fate of the other ships. With Seneca, however, the following units can be distinguished in the messenger's narration - whose name is known, unlike in the Greek play; he is called Eurybates:

(1) Sailing from Troy with favourable winds (421-448);

(2) The appearance of dolphins (449-455);

(3) Sunset and meteorological phenomena foretelling the approach of the storm $(456-469)$;

(4) The storm (470-527): (a) the natural phenomena, (b) the reaction of people;

(5) The punishment of Ajax (528-556): Athena borrows Jupiter's thunderbolts and hurls them at Ajax to revenge Cassandra's rape (obviously this motif links the story with the plot). Although the thunderbolt breaks a part of his ship on which Ajax is standing, it does not kill him and he escapes to a rock, but there is confronted with Neptune, who, emerging from the sea, strikes the cliff with his trident and drowns him;

(6) Nauplius' trap: he entices the ships that had lost their orientation in the storm to a rocky coast and runs them aground. He causes even more serious damage than the winds $(556-576)$;

(7) Dawn breaks and the storm ends (576-579).

The three chief structural patterns are the storm, the death of Ajax, and the trap of Nauplius. The Senecan narration has practically nothing to do with Aeschylus as has been shown by Tarrant in his commentary to this play. The few similar expressions can rather be ascribed to the similar subject. ${ }^{7}$ Almost the same holds true for

${ }^{7}$ TARRANT, R. J.: Agamemnon. Cambridge 1976, ad v. 393 ff. 
the other potential sources. ${ }^{8}$ The conclusion is even clearer if we compare the narrative insert of 171 verses in Hercules Furens with Euripides' Herakles mainomenos. In the Greek tragedy there is no report of Hercules' deeds in the underworld.

There can be no doubt that the generic relatives of narrative inserts are to be found not in the dramatic genre, but in the epic one. Both the sea storm and the journey of the hero to the underworld are well known topics of the epic poetry; furthermore, the Aeneid, which by this time had become a required reading in the schools, can be regarded as the source of the details. Though the scholar is inclined to assume a generic relationship between different texts on the basis of more or less convincing similarities of language, in this case even the most sceptical reader will hardly deny a close connection. The topics themselves show a parallelism (the sea storm and the journey to the underworld) and the character of the narration is epic; Eurybates and Theseus retell the stories in an objective tone that does not completely fit into the dramatic diction, despite being participants of the events they relate. It might surprise the reader or audience that they tell the story in the third person and that with epic omniscience they relate things, circumstances and emotions that they, as eyewitnesses, could hardly know. ${ }^{9}$ The language of the messenger speeches is full of epic vocabulary. This general epic character had been indicated by the textual allusions. The keryx of the Greek tragedy expresses his emotions relating the events, Eurybates does something similar only in the very first verses of his speech: Acerba fatu poscis, infaustum iubes / miscere laeto nuntium (416) which is hardly more than infandum, regina, iubes renovare dolorem (Aeneid 2.4) and all the time of the narration he stands outside his story. As appropriate to the epic genre, he quotes the word of the involved persons in direct speeches in relatively long extent (in about 10 verses in each case).

One could cite countless instances of parallel passages; suffice it here to quote some from Agamemnon to illustration the close connection: it is joyful to see the empty plain of Troy from the receding ships: iuvat videre muda Troiae litora / iuvat relicti sola Sigei loca. (435), echoing book 2 of the Aeneid, where the Trojan troops view the empty area after the withdrawal of the Greek army with similar joyful feelings: iuvat ire et Dorica castra / desertosque videre locos litusque relictum (2. $27 \mathrm{f}$.) The familiar story is this time retold from a special Greek point of view. Characteristically enough for Seneca, these allusions abound in ironies: the joy of both armies later turned out to be a little premature - because of the unexpected return of the Greek army for the Trojans, and because of the storm that causes an even bigger destruction of their forces than the long war did for the Greeks. The royal ship gives the signal to return home: signum recursus regia ut fulsit rate $(427)$ - cf. with flammas cum regia puppis / extulerat (2. $257 \mathrm{f}$.). At last, the struggling sailors in the storm say that happy are those who fell in the battle: Quisque ad Troiam / iacet felix vocatur, cadere qui meruit gradu, / quem fama servat (514 ff.). In the Aeneid: O ter-

\footnotetext{
${ }^{8}$ The Cyclic epic poems seem to have connected the motif of the sea storm with that of Aiax's death for the first time. Cf. further TARRANT, ibid.

${ }^{9}$ For example, Theseus gives a detailed report on Hercules' journey to the underworld, even though he only met the hero in the palace of Dis.
} 
que quaterque beati, quis ante ora patrum Troiae sub montibus altis / contigit oppetere! (1. $94 \mathrm{ff}$.).

The mutual references of the works are perhaps even more evident in the case of Hercules Furens, since although the Aeneid is the most important epic work of the Romans, it is not the only one, and all of them contain a storm scene, thus the question of imitation is rather complex. In the report of Eurybates there are some echoes of the sea storm scene from the Metamorphoses that was deeply influenced by the corresponding passage of the Aeneid. In Hercules Furens, the imitative situation is a bit less ambiguous. Hercules' path to the underworld follows that of Aeneas (Charon, the souls of the dead, Cerberus). Even the small details are highly similar; Charon's boat sinks under the weight of both heroes. ${ }^{10}$ But the similitude changes into deliberate opposition when the subject of narration is Hercules' behaviour towards the inhabitants of the underworld. Aeneas (or his companion Sibylla) always tried to find a peaceful way of solving critical situations, while Hercules exclusively uses violence to assert his will. The effect of the texts rests on the dynamism of similarities and differences.

Whereas these are only the messenger speeches that constitute closed inserts of epic character in which the mimesis results not through praxis, but words, and thus they offer the best examples of the mixed generic nature of Senecan drama; at the same time, the presence of epic qualities is not restricted to these parts. The choral odes, monologues and dialogues reveal certain patterns that had been borrowed from epic poetry. Most important of these is the application of ekphraseis in the text, the narrative interpretation of the action by one of the characters and the description of the outward appearance of some personae that is completely alien to the practice of Greek theatre. These phenomena have already been analyzed by V. S. Tietze who, however, did not discuss the generic problem of the messenger speeches. ${ }^{11}$

Consequently, Seneca had made even more heterogeneous the literary form that, according to the insight of modern recipient, was not completely homogeneous even in its classic form, in part by applying epic inserts, and in part by bringing dramatic diction nearer to the epic one. It is Seneca's epic theatre that consciously integrates different literary forms. The result of his efforts is basically different from Greek tragedy and requires the recipients to build up absolutely different expectations. It repeatedly breaks the empathic illusion of the drama, demands an advanced abstraction and builds on the previous aesthetic experience of its audience. This consciously heterogeneous origin of the experience resembles the modern opera most of all. As arias, recitatives, ensembles, symphoniettas and ballet inserts succeed each other in the opera, totally neglecting sometimes the common verisimilitude, so in Senecan drama the long prologues, choruses, monologues and messenger speeches demand a high degree of abstraction. The theatre of Seneca is not an institution of democracy, it offers an intellectual experience for an exclusive audience. It is of course important to emphasize that it is a matter of proportions. There were messenger

\footnotetext{
${ }^{10}$ Cf. H. F. 776-777 with Ae. 6. 413-414.

${ }^{11}$ TIETZE, V, S.: Seneca's Epic Theater. Studies in Latin Literature arrcl Roman History V. Edited by C. Deroux. Collection Latomus 206. Bruxelles 1989, 279-304.
} 
scenes in classic Attic tragedy and these scenes might have contained some non-dramatic parts; what Seneca did is nothing else but a radical change of proportions. Nevertheless, we must agree that we do not even know for sure how significant the changes introduced by Seneca were. Since only fragments of the earlier Roman and Hellenistic Greek dramas have survived, it is unclear whether Roman theatre had had an epic character even before Seneca. However, it would be too naive to conceptualize the theatre like a late realization of Attic tragedy in Latin before Seneca, i.e. the theatre of the Augustan period - we can be quite certain that Seneca had realized a far-reaching modification on the generic model inherited. This conclusion can be drawn on the grounds that every important author of the epoch had innovated, in some way or other, the norms of the literary form he cultivated. The radical innovation of the classical norms of language, style and genre is one of the most characteristic features of the literature of the Neronian age. The meaning and importance of the innovation made by Seneca cannot be judged separately from the most important literary achievements of the period, Lucan's Bellum Civile in epic poetry ${ }^{12}$ and Petronius' Satyricon, a form that can hardly be exactly defined. It is worthwhile to compare the epic inserts of Senecan drama with the latter one. The prosaic novel of loose structure and plot contains a great number of lyric inserts, ${ }^{13}$ but their extension and formation does not generally differ from the usual lyric utterance put in the mouth of the characters. There are two exceptions, however. Both of them come from the poet Eumolpus. The first epic inset is shorter (65 verses) in iambic trimeter (!) about the destruction of Troy that retells the well-known story from the Aeneid. The second one has a perhaps even greater significance for Senecan drama. The Bellum Civile of almost 300 verses (i.e. about the half of a usual book of an epic poem) stands in undeniable genetic relationship with the work of Lucan. This lengthy insert abandons the confines of plot, such as the messenger speeches in Senecan tragedy, and displays a different stylistic or aesthetic ideal than the other parts of the work. Seneca's method can seem strange regarded from the point of view of the development of the dramatic genre, but it is not unexpected at all in the literary practice of the epoch. The reform of closed literary forms and generic heterogeneity are not singular phenomena in the literary life of this innovative period.

Eötvös Loránd University

Latin Department

H-1364 Budapest P.O. Box 107

12 The most often mentioned innovation of Lucan's epic poetry is the absence of the divine apparatus. Nevertheless the structure of the plot, the cumulative descriptions and abundancy of catalogues prove better the bold innovative power of the poet.

${ }^{13}$ This is why some scholars regard the work as a Menippan satire. Cf. CofFEY, M.: Roman Satire. London 1976, 178-203. 